\title{
HADITS PEREMPUAN MELAKUKAN PERJALANAN TANPA MAHRAM PERSPEKTIF HERMENEUTIKA PAUL RICOEUR
}

\author{
Ummi Hasanah \\ Universitas Islam Negeri Syarif Hidayatullah Jakarta \\ Jalan Ir. H. Juanda No.95, Pisangan Ciputat Timur, Tangerang Selatan, 15412 \\ ummihasanah1712@gmail.com
}

\author{
Ahmad Rajafi \\ Institut Agama Islam Negeri Manado \\ Jl. Dr. S.H. Sarundajang Kawasan Ringroad I, Kota Manado, 95128 \\ ahmad.rajafi@iain-manado.ac.id
}

\begin{abstract}
Hadits about Mahram which related to women traveling is one of argueable social phenomenon in Islam. There are those who do textual approach and contextual approach in seeing this. Therefore, a new alternate of seeing this as responsive as in the contextual concept in discussing the hadits is required with the outline topic; how Paul Ricoeur hermeunetics sees the hadits about women traveling without mahram? The result is that the mahram role in the hadits is a concrete form of prevention to women in order to protect them from any kind of violences and harassments. The practice of prevention is done by the instruments provided by the country out of the women family member called mahram, this approach result is summarized the contextual meaning without neglecting the textual meaning of mahram.
\end{abstract}

Keywords: Hadits, Mahram, Hermeunetics Paul Ricoeur

\begin{abstract}
Abstrak. Hadits tentang mahram bagi perjalanan seorang perempuan merupakan salah satu fenomena sosial yang diperdebatkan di dalam Islam. Ada yang membacanya melalui pendekatan tekstual dan ada pula yang membacanya dalam kerangka kontekstual. Untuk itu, dibutuhkan alternatif bacaan baru yang dirasa responsif dalam ranah kontekstual ketika membahas hadits tersebut, dengan inti pembahasan yakni; bagaimana hermeneutika Paul Ricoeur membaca tentang hadits perempuan melakukan perjalanan tanpa mahram? Hasilnya adalah, bahwa peran mahram dalam hadits tesebut merupakan bentuk pencegahan secara konkrit bagi perempuan atas segala kekerasan yang akan menimpanya. Pencegahan tesebut tidak hanya dilakukan oleh keluarga dekat perempuan tapi juga oleh instrumen-instrumen yang diciptakan oleh negara dan dapat disebut pula sebagai mahram, sehingga pendekatan ini merangkum pemaknaannya secara kontekstual namun tidak melepaskan ati mahram secara tekstual.
\end{abstract}

Kata Kunci: Hadits, Mahram, Hermeneutika Paul Ricoeur 


\section{Pendahuluan}

Konsep mahram bukan hanya sekali atau dua kali diperbincangkan dalam dunia pemikiran Islam. Kata mahram berasal dari lafal harâm yang berarti terlarang atau dilarang dan merupakan ism maf'ûl, bentukan dari kata harama (fi'il mâdhi), atau bisa juga harima dan haruma, dengan jama'-nya mahârim dan memiliki makna mâ lâ yahillu intihâkuhâ, yaitu sesuatu yang tidak boleh dilanggar. ${ }^{1}$

Kata mahram itu sendiri telah disebutkan di dalam al-Qur'ān surat anNisā ayat 22 sampai $24,{ }^{2}$ dan dalam alQâmus al-Muhît dikatakan rahimunmahramun maknanya muharramun tazawwajuhâ, ${ }^{3}$ yang berarti mereka yang haram untuk dikawini.

Nur Rofiah, aktivis dan peneliti isu-isu hak-hak perempuan mengatakan bahwa pada umumnya mahram ini muncul dalam konteks membedakan antara laki-laki dan perempuan asing (yang tidak ada ikatan saudara atau nasab) dengan yang bukan.

Mereka yang tidak termasuk dalam kategori mahram di anggap sebagai orang asing yang harus dijaga "jarak aman"-nya sehingga mempunyai etika relasi yang berbeda dengan mahram. Misalnya boleh menikahi,

1 Luîs Ma'lûf, al-Munjid fî al-Lughah wa al-A'lâm, Cet. XCII (Beirut: Dâr al-Masyriq, 2007), h. 128.

\footnotetext{
2 Diharamkan atas kamu (mengawini) ibu-ibumu; anak-anakmu yang perempuan; saudara-saudaramu yang perempuan, saudarasaudara bapakmu yang perempuan; saudarasaudara ibumu yang perempuan; anak-anak perempuan dari saudara-saudaramu yang lakilaki; anak-anak perempuan dari saudarasaudaramu yang perempuan; ibu-ibumu yang menyusui kamu; saudara perempuan sepersusuan; ibu-ibu isterimu (mertua); anakanak isterimu yang dalam pemeliharaanmu dari isteri yang telah kamu campuri, tetapi jika kamu belum campur dengan isterimu itu (dan sudah kamu ceraikan), maka tidak berdosa kamu
}

membatalkan wudhu, tidak berhak mendampingi perempuan ketika bepergian, tidak boleh berjabat tangan dan tidak boleh berduaan. Salah satu fenomena yang terjadi di masyarakat adalah pemahaman perlunya mahram bagi perempuan yang hendak bepergian.

Terdapat beberapa hadits yang melarang perempuan bepergian tanpa disertai mahram nya, salah satunya adalah yang diriwayatkan oleh Imam alBukhari.

$$
\text { لا تسافر المرأة ثلاثا إلا مع ذى محرم.4 }
$$

Artinya: "Janganlah seorang perempuan melakukan perjalanan selama tiga hari kecuali bersama mahram nya."

Atas dasar ini, yang berstatus mahram boleh menemani karena tidak boleh menikahi dan yang bukan mahram tidak boleh menemani karena boleh menikahi, ${ }^{5}$ demikian pendapat alNawawî dalam kitab Syarh Sahih Muslim.

Jumhur ulama memahami hadits tersebut cenderung literalistik, sehingga menurut mereka bagaimanapun seorang perempuan ketika akan melakukan perjalanan jauh yang

mengawininya; (dan diharamkan bagimu) isteriisteri anak kandungmu (menantu); dan menghimpunkan (dalam perkawinan) dua perempuan yang bersaudara, kecuali yang telah terjadi pada masa lampau.

${ }^{3}$ A.W. Munawwir, Kamus Al-Munawwir Arab-Indonesia Terlengkap, Edisi II (Surabaya: Pustaka Progresif, 1997), h. 257.

4 Muhammad bin Isma'il Abu Abdillah al-Bukhari al-Ja'fi, al-Jami' ash-Shahih alMukhtashar, (Beirut: Dar Ibn Katsir, 1987), Juz. 1, h. 369

5 Al-Nawawî, Shahih Muslim bi Syarh alNawawî II, (Beirut: Dâr al-Fikr, t.th.), h. 103 
sifatnya mubah atau sunnah harus didampingi oleh mahram-nya. ${ }^{6}$

Fenomena lainnya terjadi ketika sebuah peraturan daerah syariat ditetapkan, salah satu contohnya adalah Perda Kabupaten Goa Nomor 7 tahun 2003 tentang larangan perempuan berjalan sendirian atau berada di luar rumah tanpa ditemani mahram-nya, khususnya pada selang waktu pukul $24.00 .^{7}$

Meski di sebagian daerah belum ada tanda-tanda usulan pelaksanaan syari'at Islam tersebut, namun hal ini tentunya telah menciptakan kegaduhan intelektual dan sosial bagi kaum perempuan muslim.

Pertanyaannya utamanya adalah, kenapa harus bersama mahram? Abdul Mustaqim menyatakan, bahwa maksud mahram dalam al-Qur'ân berkaitan dengan konsep munakahat dimana di situ dilarang menikahi para mahram, dan maksud lainnya adalah memberikan perlindungan, karena kenyataannya keluarga dekat yaitu mahram yang memberikan perlindungan biasanya memiliki jalinan emosional yang cukup kuat, sehingga pengaman dan perlindungan bisa diberikan. ${ }^{8}$ Namun, jika perempuan tersebut tidak memiliki mahram, lantas siapa yang dapat memberikan perlindungan baginya?

Oleh karenanya, jika hadits tentang penyertaan mahram dalam perjalanan perempuan dipahami secara tektualis, maka akan menciptakan ketimpangan hak antara perempuan dan laki-laki. Persoalan ini dapat

6 Muhyiddin Abu Zakariyya bin Syaraf an-Nawawi, Syarah Shahih Muslim, (Beirut: Darul Kitab, t.th.), Jil. V, h. 104-105

7 Sabid HM., "Rekonstruksi Fiqh Jinayat Terhadap Perda Syariat Islam," Islamica, Vol. 6, No. 2, (2012), h. 331

8 Abdul Mustaqim, "Konsep Mahram dalam Al-Qur'ân (Implikasinya dalam Mobilitas mendeskriditkan ajaran Islam yang dianggap menghambat gerak perempuan. ${ }^{9}$

Selain itu, kekerasan terhadap perempuan akan semakin marak terjadi, maka semestinya re-interpretasi terhadap hadits ini perlu dilakukan, sehingga Islam sebagai agama yang rahmatan lil 'alamin bisa menjamin hakhak perempuan, keselamatan dan keamanan bagi perempuan.

Diakui atau tidak, sebagian besar umat Islam masih berpegang teguh pada teks, baik al-Qur'ân dan hadits, namun mestinya kita tidak terjebak pada teks yang legalistik-formalistik, melainkan bagaimana mengambil pesan moral yang ada dibalik teks tersebut.

Salah satunya hadits Nabi, yang merupakan salah satu sumber utama agama Islam di samping al-Qur'ān, mengandung ajaran yang bersifat universal, temporal dan lokal. ${ }^{10}$

Oleh karenanya dibutuhkan bacaan baru dengan pendekatan lainnya, termasuk melalui pendekatan hermeneutika sebagaimana yang dipolakan oleh Paul Ricoeur.

Richard E. Palmer menempatkan posisi hermenutika Paul Ricoeur pada hermeneutika sebagai sistem interpretasi. Paul Ricoeur adalah seorang filosof kondang yang juga dikenal sebagai tokoh hermeneutik dari Perancis Selatan.

Hermeneutika didefinisikan oleh Ricoeur dalam From Text to Action: Essays in Hermeneutics, sebagai teori

Kaum Perempuan di Ranah Publik)," Musawa, Vol. 6, No. 1 (2010), h. 11

9 Atiyatul Ulya, "Konsep Mahram Jaminan Keamanan atau Pengekangan Perempuan," Al-Fikr, Vol. 17, No. 1 (2013), h. 238

10 M. Syuhudi Ismail, Hadits Nabi yang Tekstual dan Kontekstual (Jakarta : PT Bulan Bintang, 2009), h. 4 
interpretasi teks (the theory of the operations of understanding in their relation to the interpretation of texts). ${ }^{11}$

Interpretasi teks yang dimaksud adalah sebuah pembacaan makna yang tersembunyi di dalam teks yang mengandung makna yang tampak. Paul Ricoeur mengemukakan konsep cakrawala atau horizon, baik terhadap teks maupun pada manusia yang dalam hal ini adalah seorang pembaca. Pada akhirnya, interpretasi teks inilah yang dapat digunakan untuk menyingkap makna kenyataan yang tersembunyi di dalam teks.

Pendekatan hermeneutika di atas menjadi penting untuk mulai menanggalkan pemahaman klasik yang cenderung tekstualistik-formalistik. Dalam ranah hadits Nabi saw sendiri, bila hadits telah dinyatakan shahih, maka ia akan diterima tanpa penelahaan substansinya lebih lanjut. Pendekatan ini memberikan kesan kecenderungan untuk mengabaikan nalar, akal intelek dan daya intuisi.

Namun, terlepas dari perdebatan tersebut sejumlah cendikiawan muslim telah menggunakan metode hermeneutika ini dalam kajian keislaman termasuk interpretasi memahami dan memaknai hadits. ${ }^{12}$ Atas semangat pembaruan tersebut, maka artikel ini secara khusus akan berusaha menganalisa hermeneutika Paul Ricoeur sebagai sebuah teori untuk memahami hadits terkait mahram.

\section{Metode Penelitian}

Penelitian ini merupakan penelitian kualitatif dengan sumber datanya berupa dokumen kepustakaan

11 Paul Ricoeur, From Text to Action: Essays in Hermeneutics. Penerjemah Kathleen Blamey and John B. Thompson (Evanston: Northwestern University Press, 1991), h. 149 dengan cara menelusuri kitab-kitab, buku ilmiah dan referensi tertulis lainnya.

Sumber primer yang menjadi rujukan utama adalah hadits yang terdapat dalam kitab Sahîh al-Bukhâri, Shahîh Muslim, Sunan al-Turmudzi, Sunan Abû Dâud, Sunan Ibn Mājah, Musnad Ahmad bin Hanbal dan Sunan al-Dârimiy.

Sedangkan sumber tulisan yang menjelaskan metode hermeneutika untuk memahami sebuah teks, diantaranya buku "Hermeneutika Kontemporer" karya Josef Bleicher yang diterjemahkan oleh Ahmad Norma Permata (2003), buku "Teori Interpretasi" Paul Ricoeur yang diterjemahkan oleh Musnur Hery (2015) dan disertasi Fariz Pari yang berjudul "Hermeneutik Paul Ricoeur untuk Penelitian Keagamaan: Kajian Metodologi dan Terapan terhadap Kebudayaan Shalat dan Makam Sunan Rohmat Garut" pada tahun 2005.

Dalam mengumpulkan data-data, digunakan aplikasi Maktabah alSyâmilah untuk menyajikan data-data yang memadai. Disamping itu, aplikasi ini sangat lebih mudah digunakan. Setelah data-data terkumpul, digunakan metode hermeneutika di atas, di mana ada dua proses interpretasi sebagai proses analisis data, yaitu proses semiologi struktural dan proses apropriasi.

Proses analisis data teks hadits secara semiologi struktural adalah dengan cara menerjemahkan tandatanda berbahasa Arab dan selanjutnya melakukan cakrawala dari teks tersebut, lalu melakukan cakrawala peneliti terhadap teks.

12 Ansor Bahary, "Memahami Hadits "Kepemimpinan Wanita (Studi Interpertasi Hermeneutika-Gender Khaled M. Abou El Fadl)," Narasi, Vol.1 No.1 (2015), h. 13 
Berdasarkan cakrawala teks dan cakrawala pengkaji, maka dilakukan interpretasi terhadap teks tersebut sebagai bentuk interpretasi apropriasi pengkaji. Hasil apropriasi pengkaji kemudian dibandingkan dengan teks keagamaan untuk menemukan kesesuaian atau ketidaksesuaian dengan pemahaman dari teks keagamaan. Seluruh proses tahapan di atas dilakukan evaluasi dan analisis lebih lanjut untuk menjawab permasalahan dan berbagai implikasi hasil kajian ini.

\section{Hadits tentang Mahram dalam Kitab- kitab Hadits}

Redaksi hadits tentang mahram setelah ditelusuri melalui Maktabah alSyâmilah dengan kata kunci " لا تسافر المرأة ", maka ditemukan beberapa hasil temuan yang terdapat dalam kitab hadits Sahîh al-Bukhârī, Shahîh Muslim, Sunan alTurmudzi, Sunan Abû Daud, Sunan Ibn Mājah, Musnad Ahmad bin Hanbal dan Sunan al-Dârimiy.

1. Imam al-Bukhârī

حدثنا إسحق بن إبراهيم الحنظلي قال قلت لأبي أسامة حدثنم عبيد الله عن نافع عن ابن عمر رضي الله

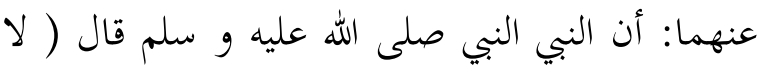
تسافر المرأة ثلاثة أيام إلا مع ذي محرم )13

Artinya: “...Tidak boleh bagi seorang perempuan melakukan perjalanan atau bepergian selama tiga hari kecuali bersama mahram -nya."

13 al-Bukhari, Sahîh al-Bukhâri, juz 2, Bâb Fii Kam Yaqsiru al-Shalâti, no. 1086 1087
حدثنا مسدد قال حدثنا يهيى عن عبيد الله عن نافع عن ابن عمر رضي الله عنهما عن النبي النبي صلى الله عليه و سلم قال: ( لا تسافر المرأة ثلاثا إلا مع ذي محرم )14 Artinya: “...Tidak boleh bagi seorang perempuan melakukan perjalanan atau bepergian selama tiga hari kecuali bersama mahram -nya."

حدثنا أبو النعمان حدثنا حماد بن زيد عن عمرو عن أبي معبد مولى ابن عباس عن ابن عباس رضي الله عنهما قال: قال النبي صلى الله عليه و سلم ( لا تسافر المرأة إلا مع ذي محرم ولا يدخل عليها رجل إلا ومعها محرم )

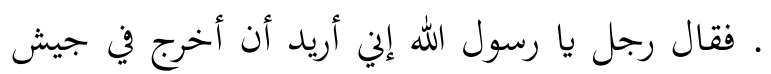
كذا وكذا وامرأتي تريد الحج ؟ ـ فقال ( اخرج معها )15 Artinya: “Abu Nu'man telah bercerita kepada kami, Hammad bin Zaid dari Abi Ma'bad budak Ibn 'Abbas dari Ibn 'Abbas bahwa Rasulullas saw bersabda; Janganlah seorang perempuan bepergian kecuali bersama mahram, dan janganlah seorang laki-laki menemuinya kecuali ia (perempuan itu) bersama mahram. Seseorang berkata; wahai Rasulullah saw saya ingin pergi keluar untuk berperang, tetapi istriku ingin pergi haji, maka Rasul menjawab; berangkatlah bersamanya (istrimu)."

2. Imam Muslim

حدثنا زهير بن حرب ومحمد بن المثنى قالا حدثنا يهيى ( وهو القطان ) عن عبيدالله أخبرني نافع عن ابن عمر أن رسول الله صلى الله عليه و سلم قال: لا تسافر المرأة ثلاثا إلا ومعها ذو محرم

Artinya: "....Tidak boleh seorang perempuan melakukan perjalanan atau

15 al-Bukhari, Sahîh al-Bukhâri, juz 3, Bâb Hajju al-Nisâ, no. 1862

16 Muslim, Shahîh Muslim, juz 2, Bāb Safara Mar'ah ma'a Mah́ramin, no. 413 
bepergian selama tiga hari kecuali bersama mahram-nya."

حدثنا عثمان بن أبي شيبة حدثنا جرير عن مغيرة عن إبراهيم عن سهم ابن منجاب عن قزعة عن أبي سعيد الخدري قال قال رسول الله صلى الله عليه و سلم: لا

$$
\text { تسافر المرأة ثلاثا إلا مع ذي محرم } 17
$$

Artinya: “...Tidak boleh bagi seorang perempuan melakukan perjalanan atau bepergian selama tiga hari kecuali bersama mahram-nya."

3. Imam al-Tirmidzî

روي عن النبي صلى الله عليه و سلم أنه قال لا تسافر

$$
\text { المرأة مسيرة يوم وليلة إلا مع ذي محرم } 18
$$

Artinya: “...Tidak boleh seorang perempuan melakukan perjalanan atau bepergian siang dan malah hari kecuali bersama mahram-nya."

4. Imam Abû Dāud

حدثنا أحمد بن حنبل ثنا يميى بن سعيد عن عبيد الله قال حدثني نافع عن ابن عمر : عن النبي صلى الله عليه و سلم قال: لا تسافر المرأة ثلاثا إلا ومعها ذو محرم 19

Artinya: “...Tidak boleh bagi seorang perempuan melakukan perjalanan atau bepergian selama tiga hari kecuali bersama mahram-nya."

5. Imam Ibnu Mâjah

حدثنا على بن محمد حدثنا وكيع حدثنا الأعمش عن أبى صالح عن أبى سعيد قال قال رسول الله -صلى الله

17 Muslim, Shaḥîh Muslim, juz 2, no. 417

18 At-Tirmidzî, Sunan al-Turmuzi, Bāb Mà Jā'a fi Karahiyati an Tusafiru al-Mar'ah Wahdaha, Juz 3, no. 1169

${ }^{19}$ Abû Dâud, Sunan Abû Dâud, juz 5, Bāb fi al-Mar'ati Tuhijju Bighairi Mah̆ramin, no. 1727

${ }^{20}$ Ibnu Mâjah, Sunan Ibn Mâjah, Bab alMaratu Tahujju bi Ghair Waliyyin, juz 9, no. 2898
عليه وسلم- > لا تسافر المرأة سفر ثلاثة أيام فصاعدا إلا مع أبيها أو أخيها أو ابنها أو زوجها أو ذى حرمب20 Artinya: “...Tidak boleh seorang perempuan melakukan perjalanan selama tiga hari kecuali bersama bapaknya atau saudaranya atau anaknya atau suaminya atau orang lain yang satu maham-nya."

6. Imam Ahmad bin Hanbal

حدثنا يميى ، عن عبيد الله ، حدثني نافع ، عن عبد الله بن عمر ، عن النبي صلى الله عليه وسلم قال: لا تسافر المرأة ثلاثا إلا ، ومعها ذو محرم 21

Artinya: "...Tidak boleh bagi seorang perempuan melakukan perjalanan atau bepergian selama tiga hari kecuali bersama mahram-nya."

حدثنا ابن نمير حدثنا عبيد الله عن نافع عن ابن عمر عن النى -صلى الله عليه وسلم- قال 》 لا تسافر المرأة ثلاثا إلا مع ذى محرم «22

Artinya: “...Tidak boleh bagi seorang perempuan melakukan perjalanan atau bepergian selama tiga hari kecuali bersama mahram-nya."

7. Imam al-Dārimiy

حدثنا يعلى ثنا الأعمش عن أبي صالح عن أبي سعيد قال قال رسول الله صلى الله عليه و سلم: لا تسافر المرأة

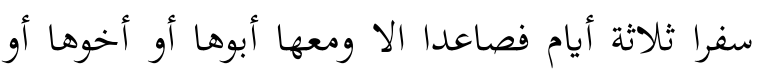
زوجها أو ذو رحم محرم منهما23

${ }^{21}$ Ahmad bin Hanbal, Musnad Ahmad bin Hanbal, Bab Musnad Abdullah bin Umar, juz.8, no. 4615

${ }^{22}$ Ahmad bin Hanbal, Musnad Ahmad bin Hanbal, Bab Musnad Abdullah bin Umar, juz.10, no. 6289

23 al-Dârimiy, Sunan al-Dârimiy, Bâb Fii Igtisâl, no. 2720 
Artinya: “...Tidak boleh seorang perempuan melakukan perjalanan selama tiga hari kecuali ditemani ayahnya atau saudara laki-lakinya atau suaminya atau mahram-nya."

\section{Klasifikasi Mahram Dalam Islam}

1. Faktor Nasab

a. Ibu. Ibu di sini adalah perempuan yang mengandung dan melahirkan anak laki-laki. Hubungan antara ibu dan anak inilah yang menyebabkan adanya ikatan mahram . Lalu ibunya dari ibu, yaitu nenek hingga ke atas, baik dari jalur bapk atau jalur ibu. ${ }^{24}$

b. Anak Perempuan. Anak perempuan di sini adalah anak yang dilahirkan oleh istri maupun anak kandung. Anak perempuan hingga ke bawah baik cucu perempuan dari anak laki-laki dan cucu perempuan dari anak perempuan. Termasuk anak kandung dan tiri, cucu dan cicit dengan semua tingkatannya.

c. Saudara Perempuan, yaitu saudara-saudara perempuan sekandung, sebapak atau seibu.

d. 'Ammah, yaitu bibi dari pihak ayah, perempuan yang menjadi saudara kandung ayah, atau saudara perempuan ayah dari salah satu orang tua ayah. Termasuk saudara-saudara perempuan kakek, baik sekandung, sebapak dan seibu.

24 Muhammad bin Ibrahîm Alu asySyaikh, Fatwa-fatwa tentang Wanita Penerjemah Majmuah (Jakarta: Darul Haq, 2011), h. 148

25 H.M.A. Tihami dan Sohari Sahran, Fikih Munakahat (Jakarta: Rajawali Press, 2009), h. 69 e. Khalah, yaitu bibi dari pihak ibu. Saudara-saudara ibu atau saudara-saudara nenek yang perempuan hingga ke atas, baik sekandung, sebapak atau seibu.

f. Anak perempuan dari saudara laki-laki. Mereka adalah keponakan, anak perempuan dari saudara laki-laki, baik kandung maupun anak tiri.

a. Anak perempuan dari saudara perempuan. Mereka adalah keponakan, anak perempuan dari saudara perempuan, baik sekandung, sebapak atau seibu.

2. Faktor Perkawinan ${ }^{25}$

a. Mertua perempuan, nenek perempuan istri dan seterusnya ke atas, baik dari garis ibu atau ayah.

b. Anak tiri, dengan syarat kalau telah terjadi hubungan kelamin antara suami dengan ibu anak tersebut. Termasuk juga cucu perempuan baik dari anak lakilaki maupun anak perempuan. ${ }^{26}$

c. Menantu, yaitu istri anak, istri cucu dan seterusnya ke bawah.

d. Ibu tiri, yaitu bekas istri ayah, untuk ini tidak disyaratkan harus adanya hubungan seksual antara ibu dan ayah.

3. Faktor Persusuan

a. Ibu susuan (perempuan yang menyusui, karena ia berada di posisi ibu bagi anak yang disusuinya).

26 Abd al-'Azim, al-Wajiz fi Fiqh alSunnah wa al-Kitâb al-'Azîz (Madinah: Dâr alTaqwid, 1995), h. 287 
b. Ibu dari ibu susuan, karena ia berstatus nenek bagi anak yang disusui.

c. Ibu dari suami ibu susuan (mertua ibu susu), karena ia juga nenek bagi anak yang disusui.

d. Saudara perempuan ibu susuan, karena ia adalah bibi baginya.

e. Saudara perempuan dari suami ibu susuan.

f. Anak keturunan ibu susuan, baik dari pihak ayah dan ibu susuan maupun salah satu pihak saja.

g. Saudara perempuan sesusuan, baik dari pihak ayah dan ibu susuan maupun salah satu pihak saja

Penjelasan seputar susuan ini dapat dikemukakan beberapa hal:

a. Susuan yang mengakibatkan keharaman perkawinan ialah susuan yang diberikan pada anak yang memah masih memperoleh makanan dari air susu.

b. Mengenai berapa kali seorang bayi menyusui pada seorang ibu yang menimbulkan pengharaman, Imam Mālik dan Imam Hanafi menyatakan bahwa jumlahnya tidak dibatasi, asal seorang bayi telah menyusu dan kenyang. Menurut Imam Syāfi'i, sekuramgkurangnya lima kali susuan dan mengenyangkan. Adapun pendapat Tsaur Abu Ubaid, Daud Ibnu Ali al-Zahiriy dan Ibnu Muzakkir, sedikitnya tiga

$$
\begin{aligned}
& \text { kali susuan dan } \\
& \text { mengenyangkan. }{ }^{27}
\end{aligned}
$$

Berdasarkan penjelasan di atas maka dapat dilihat bahwa mahram dalam Islam merupakan penjelasan deskriptif tentang definisi mahram dan hal-hal yang tercakup di dalamnya dan hanya membahas wilayah munakahat, sehingga belum ada implikasi-implikasi sosial yang membutuhkan wilayah tinjauan yang lainnya, seperti historis maupun sosiologis. Jika ada, hanya merupakan implikasi dari pemahaman dan hanya berkutat pada masalah pernikahan dan keluarga.

Salah satu hikmah mengapa tidak boleh menikahi mahram adalah pertama, adanya keharusan menjaga hubungan kekerabatan, serta menghormati orang-orang yang secara nasab semestinya untuk dihormati dan dijaga, sebab dimunngkinkan dalam pernikahan mereka ada perselisihan dan perceraian, sehingga bisa merusak hubungan kekeluargaan yang selama ini terjaga baik.

Kedua, beberapa ulama menjelaskan bahwa pernikahan antara keluarga dekat akan melahirkan anak cucu yang lemah jasmani dan ruhani. Bahkan Imam al-Ghazâli sebagaimana dikutip Quraish Shihab menyebut riwayat yang dinisbahkan kepada Nabi saw. dan Umar bin Khattab, antara lain: "Janganlah kamu menikahi kerabat yang dekat karena anak-anak akan lahir dalam keadaan lemah" (HR. Ibrahim alHarbi).

Ketiga, sebagian penelitian menunjukkan bahwa pernikahan antar kerabta yang dekat berpotensi menyebabkan keturunan yang mudah terjangkit penyakit cacat fisik, serta 
kesuburan rendah, bahkan mendekati kemandulan. ${ }^{28}$

\section{Hermeneutika Paul Ricoeur Terhadap Hadits tentang Mahram}

Paul Ricoeur merupakan tokoh hermeneutik yang lebih mengarahkan hermeneutika ke dalam kegiatan penafsiran dan pemahaman terhadap teks. Melalui bukunya, De' Interpretation, Paul Ricoeur mengatakan bahwa hermeneutika merupakan "teori mengenai aturan-aturan penafsiran, yaitu penafsiran terhadap teks tertentu, atau tanda, atau simbol yang dianggap sebagai teks". ${ }^{29}$

Penafsiran terhadap teks tertentu, atau tanda, atau simbol, yang dianggap sebagai teks ini menempatkan kita harus memahami "What is a text?". Teks merupakan sebuah korpus yang otonom, yang dicirikan oleh empat hal sebagai berikut.

Pertama, dalam sebuah teks, makna yang terdapat pada "apa yang dikatakan (what is said), terlepas dari proses pengungkapannya (the act of saying), sedangkan dalam bahasa lisan, kedua proses itu tidak dapat dipisahkan.

Kedua, makna sebuah teks juga tidak lagi terikat kepada pembicara, sebagaimana bahasa lisan. Apa yang dimaksud teks tidak lagi terkait dengan apa yang awalnya dimaksudkan oleh penulisnya. Bukan berarti bahwa penulis tidak lagi diperlukan, akan tetapi maksud penulis sudah terhalang oleh teks yang sudah membaku.

28 Quraish Shihab, Tafsir Al-Misbah; Pesan, Kesan dan Keserasian al-Qur'ân Vol. II, Cet.II (Jakarta: Lentera Hati, 2005), h. 392-393

29 E. Sumaryono, Hermeneutik, Sebuah Metode Filsafat, (Yogyakarta: Kanisius, 1999), h. 105
Ketiga, karena tidak terikat pada sebuah sistem dialog, maka sebuah teks tidak lagi terikat pada konteks semula (ontensive reference), ia tidak terikat pada konteks pembicaraan.

Keempat, dengan demikian juga tidak lagi terikat pada audiens awal, sebagaimana bahasa lisan terikat kepada pendengarnya. Sebuah teks ditulis bukan untuk pembaca tertentu, melainkan kepada siapa pun yang bisa membaca, dan tidak terbatas oleh ruang dan waktu. ${ }^{30}$ Maksud dari "tidak terikat" adalah tidak terikat lagi dengan makna yang dimaksud pengarang karena ada lagi tanya jawab sebab teks telah baku.

Interpretasi menurut Ricoeur adalah karya pemikiran yang terdiri atas penguraian makna yang tersirat di dalam makna yang literer. Interpretasi dilakukan dengan cara penafsir harus mengambil jarak agar dapat melakukan interpretasi hermeneutik Ricoeur melalui dua proses tahapan, yaitu; proses semiologi struktural dan proses apropriasi.

Proses semiologi struktural berfungsi sebagai kegiatan eksplanasi (erklaren), yang menjadikan teks sebagai suatu yang otonom yang terlepas dari intensi penulisnya dan juga dari dunia nyata (konteks) yang dibicarakan teks.

Tahap kedua adalah apropriasi, yaitu proses membuat teks menjadi milik kita (pembaca), mengambil manfaat dari teks, yang baginya ini proses memahami (verstehen). Dalam proses apropriasi terjadi penyatuan antara cakrawala teks dengan cakrawala pembaca (fusion of horizon). Fusion of

30 Paul Ricoeur, Filsafat Wacana, Membelah Makna dalam Anatomi Bahasa. Penerjemah Musnur Hery (Yogyakarta: Ircisod, Cet.II, 2003), h.203 
horizon merupakan cara pendekatan yang diambil dari hermeneutika Hans Gadamer.

Cakrawala oleh Gadamer juga disebut sebagai horison. Setiap orang mempunyai cakrawalanya masingmasing, yang berbeda satu sama lain. Cakrawala seseorang dipengaruhi faktor eksternal dan internal masing-masing orang yang terbentuk dalam perjalanan hidupnya yang merupakan perngalaman sejarah (historical experience) hidup seseorang.

Begitu pula sebuah teks memiliki cakrawalanya sendiri. Ketika pembaca membaca suatu teks, akan tergambar di pikirannya suatu gambaran dunia yang digambarkan oleh teks, artinya dunia yang dibicarakan teks, yang merupakan dunia yang bersifat imajiner atau khayalan. Dunia imajiner yang digambarkan oleh teks tersebut merupakan cakrawala teks.

Penyatuan cakrawala
menghasilkan pemahaman baru
terhadap dirinya dan juga terhadap
dunia tempat dia hidup, dengan
demikian ada perkembangan cakrawala
dalam diri pembaca tersebut. Ricoeur
mengadopsi pendekatan strukturalisme
dalam hermeneutiknya.

Pendekatan struktural dilihat sebagai suatu dengan baik. Seorang penafsir harus melakukan pembacaan "dari dalam" teks tanpa masuk atau menempatkan diri dalam teks teks, dan cara pemahamannya pun tidak dapat lepas dari kerangka kebudayaan dan sejarahnya sendiri.

31 Dalam konteks analisis wacana (discourse analyze), teks merupakan wacana yang telah dimapankan dalam tulisan ( any discourse fixed by writing ). Teks ini lebih menekankan aspek "worldless" dan "authorless". Sehingga makna suatu teks berada dalam termterm relasi internal dan strukturalnya. Lebih jauh Ricoeur menjelaskan bahwa teks semacam ini mengimplikasikan otonomi rangkap tiga.
Ada dua proses interpretasi, yaitu proses interpretasi semiologi struktural dan proses interpretasi apropriasi.

Dalam konteks penelitian ilmiah, baik terhadap kebudayaan secara umum ataupun kebudayaan keagamaan secara khusus, penggunaan metodologi kutub objektif (sisi metodologis erklaren) dalam proses interpretasi yang mempersiapkan kutub appropriasi (sisi ontologis verstehen) dipahami secara dialektis, sebagai dua hal yang saling melengkapi.

Teks tersebut memiliki struktur immanen yang harus didekati secara struktural, juga memiliki referensi luar di luar relasi-relasi sistem. ${ }^{31}$ Dengan proses distansiasi, immanensi teks menjadi otonom. Distansiasi menjamin otonom teks dalam hubungannya dengan pengarang sehingga membuat teks tercerabut dari konteks aslinya. Akibatnya, teks menjadi terbuka terhadap interpretasi-interpretasi, yang bisa jadi bertolak belakang dengan maksud pengarang.

Proses appropriasi muncul ketika teks telah tercerabut dari konteksnya. Dengan demikian, melakukan appropriasi berarti menjadikan apa yang asing sebagai "aku" penafsir, milik sendiri, melalui pembacaan kembali teks yang harus dimengerti dalam arti eksistensial: sebagai cara baru untuk memahami realitas dalam suatu lebenswelt. ${ }^{32}$

Melalui pendekatan hermeneutik di atas maka dapat dipahami bahwa

\footnotetext{
Yaitu otonomi teks terhadap maksud pengarang, otonomi teks terhadap situasi kultural dan kondisi sosiologis dimana teks diproduksi dan otonomi terhadap pembaca awal.

32 Edi Mulyono, Belajar Hermeneutika dari Konfigurasi Filosofis menuju Praksis Islamic Studies, h. 32-33
} 
hadits-hadits yang telah dipaparkan sebelumnya menggambarkan larangan kepada perempuan untuk bepergian sendiri selama tiga hari kecuali ada mahram yang menyertai perjalanannya, mengisyaratkan adanya perlindungan terhadap perempuan menjadi sangat diutamakan.

Konsepsinya bukan saja hanya dimaknai pada struktur keluarga, namun pula pada instrumen-instrumen lain yang diciptakan oleh manusia yang tentunya dapat berintegrasi dengan beberapa lembaga sosial dengan misi melindungi kesejahteraan perempuan yang sudah banyak ditemui.

Dalam ranah negara Indonesia misalnya, terdapat Kementerian Pemberdayaan Perempuan dan Perlindungan Anak (KEMENPPPA) yang di dalamnya memuat sederetan undangundang khusus untuk melindungi perempuan termasuk kekerasan.

Lembaga lainnya adalah Komisi Nasional Anti Kekerasan Terhadap Perempuan (KOMNAS PEREMPUAN). Lalu, peraturan presiden juga menegaskan kepala atau anggota dalam badan pemerintahan, seperti ketua RT, kepala Camat, Walikota, Gubernur, Polisi, TNI turut menjaga dan melindungi kesejahteraan perempuan. Perlindungan ini biasanya dilakukan pasca terjadinya kekerasan pada perempuan, maka dilakukan pendampingan dan penjatuhan hukuman bagi para pelaku.

Kedua, interpretasi teks hadits yang melarang perempuan melakukan perjalanan tanpa disertai mahram adalah bentuk pencegahan (sad aldzari'ah), berdasarkan peleburan cakrawala (apropriasi) yang tergambar di dalam hadits-hadits di atas ketika seorang perempuan melakukan perjalanan baik sehari, dua hari, ataupun tiga hari kecuali ada suami, saudara atau mahram-nya bersamanya.

Hal ini berintegrasi dengan beberapa peristiwa yang saat ini menimpa sebagian perempuan yang menjadi korban kejahatan. Sesuai dengan data dari Komnas Perempuan, mereka mengalami gangguan fisik dan juga psikis. Akibat fisik yang diderita korban pelecehan kekerasan diantaranya adalah cacat anggota tubuh dan kerusakan organ intim atau reproduksi, sehingga akan menyebabkan sulitnya memperoleh keturunan, terserang berbagai penyakit hingga kematian. Akibat psikis yang diderita yaitu keterancaman untuk bisa hidup normal di lingkungan sekitar, baik dalam keluarga dan masyarakat, serta tekanan mental yang luar biasa menggoncang sehingga tak jarang banyak yang melakukan bunuh diri.

Artinya, banyak perempuan yang terkena dampak fisik dan psikis dari kekerasan tersebut, baik kekerasan seksual ataupun kekerasan dalam rumah tangga. Sehingga mahram di sini mampu melakukan pencegahan secara langsung bagi si korban. Oleh karenanya, hadits ini mestinya menjadi sebuah bentuk pencegahan oleh mahram agar hal-hal di atas tidak terjadi dan menimpa perempuan.

Ketiga, interpretasi teks hadits yang melarang perempuan melakukan perjalanan tanpa mahram masih relevan dengan kondisi dan situasi saat sini. Relevansi tersebut terlihat dari cakrawala hadits-hadits di atas untuk melakukan perjalanan dan tentang keutamaan mendampingi seorang istri yang hendak berhaji dibandingkan berperang. Pendampingan dahulunya dilakukan oleh orang-orang terdekat perempuan, sedangkan pendampingan saat ini adalah adanya sederetan Undang-undang Perlindungan Perempuan dan lembaga-lembaga sosial 
dan hukum yang bertugas menaungi kesejahteraan dan keadilan bagi perempuan.

\begin{tabular}{llr}
\multicolumn{2}{c}{ Undang-undang dan lembaga } \\
tersebut memayungi \\
peraturan yeberapa
\end{tabular} menjatuhkan hukuman bagi para pelaku serta melakukan advokasi bagi korban kekerasan. Namun, pencegahan secara konkrit saat ini dilakukan oleh keluarga atau dalam hal ini adalah mahram. Sehingga hasil apropriasi ketiga ini menunjukkan bahwa hadits Nabi saw masih relevan dengan kondisi dan situasi saat ini.

Berdasarkan pemaparan di atas, maka dapat dipahami bahwa dalam memaknai arti mahram, hermeneutika Paul Ricoeur tidak mengabaikan arti hadits secara tekstual. Mahram dalam hadits tersebut tetap dimaknai sebagaimana disebutkan dalam alQur'ān dan memiliki peran dalam bentuk pencegahan secara ril bagi perempuan.

Selain daripada itu, penjelasan historikal hadits juga dicantumkan dalam pendekatan hermeneutika Paul Ricoeur sebagaimana yang tercantum dalam cakrawalas hadits. Cakrawala hadits menggambarkan kondisi peperangan dan pendampingan bagi seorang istri. Bahkan juga melakukan kontekstualisasi hadits dengan eranya, dengan menghadirkan adanya lembagalembaga atau sederetan perundangundangan yang berfungsi memberikan perlindungan bagi perempuan ataupun hukuman bagi para pelaku kejahatan, dan menempatkan peran mahram sebagai bentuk pencegahan secara ril dan konkrit terhadap kejahatan kepada perempuan.

Bacaan akhirnya adalah, bahwa hermeneutika Paul Ricoeur mampu menegasi paham bias gender dalam Islam yang menganggap perempuan lemah dan butuh pendampingan, bahkan dengan pendekatan tersebut telah menunjukkan kajian keislaman maupun gender tidak saling bertentangan bahkan sangat mungkin dilakukan integerasi yang saling melengkapi.

Secara keseluruhan, pendekatan yang ditawarkan oleh hermeneutika Paul Ricoeur memiliki banyak kesamaan dengan pendekatan ilmu hadits, khususnya pada pemaparan sisi kontekstualitas dari hadits-hadits tersebut.

\section{Kesimpulan}

Terdapat problem dalam memahami hadits terkait mahram. Dalam hadits tersebut dikatakan bahwa perempuan yang melakukan perjalanan jauh maka harus disertai oleh mahramnya, namun permasalahannya mungkinkah mahram akan selalu mendampingi perempuan dalam melakukan aktivitasnya di luar.

Hal ini juga menjadi salah satu latar belakang muculnya perda syari'at di beberapa daerah. Sementara itu, kejahatan yang terjadi pada perempuan saat ini semakin marak dan merebak, mulai dari usia muda, dewasa hingga tua, seperti pemerkosaan, pencabulan dan perampokan. Selain itu, bagaimana sebenarnya peran mahram yang tercantum dalam hadits Nabi tersebut.

Pemaknaan yang dapat di ambil melalui pendekatan hermeneutika Paul Ricoeur dari hadits yang melarang perempuan melakukan perjalanan tanpa disertai mahram adalah tidak hanya berlangsung pada struktur kekeluargaan, namun juga melalui instrumen-instrumen yang dibentuk oleh negara dalam bentuk perlindungan dari lembaga berupa sederetan perundang-undangan, aksi pejabat atau kepala pemerintahan serta masyarakat. 
Selain itu, peran mahram dalam hadits tesebut adalah bentuk pencegahan secara konkrit bagi perempuan.

\section{DAFTAR PUSTAKA}

al-'Azim, Abd., al-Wajiz fi Fiqh al-Sunnah wa al-Kitâb al-'Azîz, Madinah: Dâr al Taqwid, 1995

Alfikri Suryadinata, Ahmad., "Pemahaman Kontekstual Atas Hadits Mahram dalam Kutub Al-Tis'ah", Musâwa, Vol. 9, No. 1, 2010

An-Nawawi, Muhyiddin Abu Zakariyya bin Syaraf., Syarah Sahîh Muslim. Beirut: Darul Kitab, t.th.

asy-Syaikh, Muhammad bin Ibrahim Alu., Fatwa-Fatwa tentang Wanita. Penerjemah Majmuah, Jakarta: Darul Haq, 2011

E. Palmer, Richard., Hermeneutika: Teori Baru Mengenai Interpretasi, Penerjemah Musnur Hery daan Damanhuri Muhammad, Yogyakarta: Pustaka Pelajar, 2005

Ghazaly, Abd Rahman., Fiqh Munakahat, Jakarta: Prenada Media, 2003

HM, Sabit., "Rekonstruksi Fiqh Jinayat Terhadap Perda Syariat Islam", Islamica, Vol. 6, No. 2, 2012

Ismail, M. Syuhudi., Hadits Nabi yang Tekstual dan Kontekstual, Jakarta: PT Bulan Bintang: 2009

Kusmana, Hermeneutika Al-Qur'an: Sebuah Pendekatan Praktis Aplikasi Hermeneutik Modern dalam Penafsiran Al-Qur'an, Jakarta: UIN Jakarta Press: 2004

Ma'lûf, Luîs., Al-Munjid fí Al-Lughah wa AlA'lâm, Beirut: Dâr al-Masyriq, 2007

Mulyono, Edi. Belajar Hermeneutika dari Konfigurasi Filosofis menuju Praksis
Islamic Studies, Yogyakarta: IRCiSoD, 2012.

Munawwir, Ahmad Warson., Kamus alMunawwir Arab-Indonesia Terlengkap, Surabaya: Pustaka Progresif: 2002.

Maktabah al-Syâmilah.

Mustaqim, Abdul., "Konsep Mahram dalam Al-Qur'an (Implikasinya dalam Mobilitas Kaum Perempuan di Ranah Publik)", Musâwa, Vol. 6, No. 1, 2010

Ricoeur, Paul., From Text to Action: Essays in Hermeneutics. Penerjemah Kathleen Blamey and John B. Thompson, Evanston: Northwestern University Press, 1991 , Filsafat Wacana, Membelah Makna dalam Anatomi Bahasa, Penerjemah Musnur Hery, Yogyakarta: Ircisod, Cet.II, 2003

Shaleh, Qamaruddin, dkk., Asbabun Nuzul, Latar Belakang Historis Turunnya Ayat-Ayat Al-Qur'an, Bandung: C.V. Penerbit Diponegoro, 2007

Shihab, M. Quraish., Tafsir Al-Misbah; Pesan, Kesan dan Keserasian alQur'an II, Jakarta: Lentera Hati, 2005

Sumaryono, E., Hermeneutik, Sebuah Metode Filsafat, Yogyakarta: Kanisius, 1999

Tihami, H.M.A. dan Sahran, Sohari., Fikih Munakahat, Jakarta: Rajawali Press, 2009

Ulya, Athiyatul., "Konsep Mahram Jaminan Keamanan atau Pengekangan Perempuan", Al-Fikr, Vol. 18, No. 1, 2013

Wachid B.S., Abdul., "Hermeneutika Sebagai Sistem Interpretasi Paul Ricoeur", Ibda', Vol. 8, No. 1, 2009 
JURNAL AQLAM -- Journal of Islam and Plurality -- Volume 3, Nomor 1, Juni 2018 